\title{
Seagrass habitat disturbance: how loss and fragmentation of eelgrass Zostera marina influences epifaunal abundance and diversity
}

\author{
Brendan J. Reed ${ }^{1,2, *}$, Kevin A. Hovel ${ }^{1}$ \\ ${ }^{1}$ Department of Biology, San Diego State University, 5500 Campanile Drive, San Diego, California 92182, USA \\ ${ }^{2}$ Present address: City of Chula Vista, 276 Fourth Avenue, Chula Vista, California 91910, USA
}

\begin{abstract}
Seagrass habitats commonly display evidence of anthropogenic disturbances such as propeller scars, mooring and anchor damage, trampling, and plant harvesting. These physical disturbances may lead to habitat loss and fragmentation, yet effects of this habitat removal on seagrass epifaunal communities are not well understood. We investigated how the degree of eelgrass Zostera marina L. loss influenced the abundance, diversity, and community composition of epifauna within experimental seagrass plots in San Diego Bay, California, USA. We established replicate small $\left(4 \mathrm{~m}^{2}\right)$ and large $\left(16 \mathrm{~m}^{2}\right)$ plots within existing eelgrass habitat, and removed all aboveground and belowground plant material within randomly chosen cells to establish 4 to 6 levels of eelgrass clearing. We then sampled for epifauna up to $8 \mathrm{wk}$ after eelgrass harvesting. We found no correlations between seagrass loss and epifaunal species richness, total epifaunal density or epifaunal diversity in small plots. In large plots, however, plots with $90 \%$ habitat removal had significantly lower epifaunal species richness and total epifaunal density than plots with 0,10 or $50 \%$ habitat removal, suggesting that beyond a threshold level of eelgrass disturbance, species richness and abundance rapidly decline. Multivariate ordinations revealed that the $90 \%$ removal plots also had significantly different species composition than plots with less habitat loss. Our results support previous theoretical models predicting threshold levels of habitat loss for faunal communities and broaden our understanding of the response of marine epifauna to seagrass habitat degradation.
\end{abstract}

KEY WORDS: Seagrass disturbance - Habitat loss - Habitat fragmentation - Zostera marina . Diversity $\cdot$ Critical thresholds $\cdot$ San Diego Bay

\section{INTRODUCTION}

Human-induced disturbance of native habitats at the landscape scale is increasing worldwide, resulting in significant habitat loss and alteration (Vitousek et al. 1997). At the onset of habitat loss, the native habitat typically remains intact, but has 'perforations' in its extent (Hayward et al. 1999). As the loss continues, the original landscape becomes splintered into fragmented habitat patches embedded within a 'matrix' of unsuitable habitat in which mean habitat patch size is low and mean patch isolation is high (Fahrig 1997). These changes in habitat configuration (= habitat fragmentation per se: Fahrig 2003) can influence faunal abundance, diversity and survival independently of habitat loss (e.g. Villard et al. 1999, reviewed by Fahrig 2003). At high levels of habitat loss, however, habitat fragmentation and changes in the amount of habitat may interact to drastically modify abiotic and biotic processes (Turner 1989). The synergistic effects of habitat amount and configuration may result in threshold levels of habitat loss below which faunal abundance (Andrén 1994, Villard et al. 1999), diversity (Fahrig 2003), and survival are low. For instance, in forest habitat, bird and mammal abundance and survival typically decrease slowly 
until 70 to $80 \%$ of the habitat has been lost, and decrease rapidly thereafter (Andrén 1994).

Although habitat loss and fragmentation and their effects on fauna have been studied primarily in terrestrial ecosystems, patterns of habitat disturbance are also observed in marine environments such as seagrass meadows. Eelgrass Zostera marina, one of ca. 50 seagrass species worldwide, forms subtidal beds in shallow, temperate marine waters (Fonseca et al. 1998, Hemminga \& Duarte 2000). Designated by many federal and state agencies as a critical nursery habitat, eelgrass provides essential refuge and foraging grounds for a variety of ecologically and commercially important macrofaunal species (Peterson 1986, Pile et al. 1996, Allen et al. 2002). In addition, the density and diversity of invertebrates and fishes are usually greater in eelgrass meadows than in nearby unvegetated areas (reviewed by Orth et al. 1984).

Seagrass beds are naturally disturbed and fragmented into a variety of patch sizes and shapes by waves, currents and bioturbation. In addition, anthropogenic disturbance in seagrass beds can result from coastal development projects, propeller scarring, anchor usage, vessel groundings, fishing practices, trampling, and plant harvesting (Sargent et al. 1995, Fonseca et al. 1998, Eckrich \& Holmquist 2000). These disturbances can vary in spatial scale, but typically result in the removal of above- and belowground seagrass biomass and changes in seagrass cover and configuration. Seagrass landscape changes can influence predatorprey dynamics (Irlandi 1994, Irlandi et al. 1995, Hovel \& Lipcius 2001, Hovel 2003), faunal growth rates (Irlandi 1996, Bologna \& Heck 1999, Irlandi et al. 1999, Reusch \& Williams 1999), and species diversity and abundance (Turner et al. 1999). The effects of seagrass loss and fragmentation on fauna are typically inferred from sampling and experimentation in fragmented vs. continuous seagrass landscapes, or in small vs. large seagrass patches. Few studies on faunal responses to seagrass habitat loss and fragmentation have manipulatively fragmented naturally occurring seagrass beds (Eckrich \& Holmquist 2000), although this approach has been implemented in both prairie (Diffendorfer et al. 1995, Parker \& MacNally 2002) and forest (Laurance et al. 1998) landscapes. In addition to allowing stronger inferences to be made regarding the effects of habitat loss and fragmentation on fauna (McGarigal \& Cushman 2002), experimental removal of habitat incorporates a physical component inherent in most disturbance events (Turner 1989).

In the present study we determined whether the intensity of seagrass disturbance (i.e. habitat loss), and the spatial scale over which it occurs, influence epifaunal density, diversity, and community composition in the eelgrass habitat of San Diego Bay, California. We experimentally removed eelgrass from replicate plots of 2 sizes that approximate the scale at which seagrass is commonly fragmented by e.g. anchor damage, bioturbation and harvesting activities (small-scale plots: Townsend \& Fonseca 1998, Creed \& Amado Filho 1999, Rasheed 1999, authors' pers. obs.) and by e.g. propellers, vessel groundings and mooring gear (largescale plots: Walker et al. 1989, Bell et al. 2002, Uhrin \& Holmquist 2003). Plots were sampled for epifaunal density and diversity up to $8 \mathrm{wk}$ after initial treatment application to ensure that species were responding to the resulting habitat coverage and configuration and had not just been removed from the plots by the initial disturbance event (i.e. seagrass removal). Based on the results of studies conducted in terrestrial landscapes (e.g. Andrén 1994, Villard et al. 1999), we predicted that effects of habitat loss on epifaunal communities would not be evident until relatively high levels of loss were encountered.

\section{MATERIALS AND METHODS}

Study site. Our study was conducted in eelgrass Zostera marina L. meadows in the central and southern region of San Diego Bay, California, USA (Fig. 1). Salinity in the bay ranges from ca. 32 to $38 \mathrm{psu}$, and water temperatures range annually from 13 to $24^{\circ} \mathrm{C}$. Eelgrass dominates the shallow subtidal and intertidal areas of the bay, although patches of Ruppia maritima (widgeongrass) are also present in some intertidal areas. Water depths at our study sites varied between 0.5 and $3 \mathrm{~m}$ below mean lower low water (MLLW).

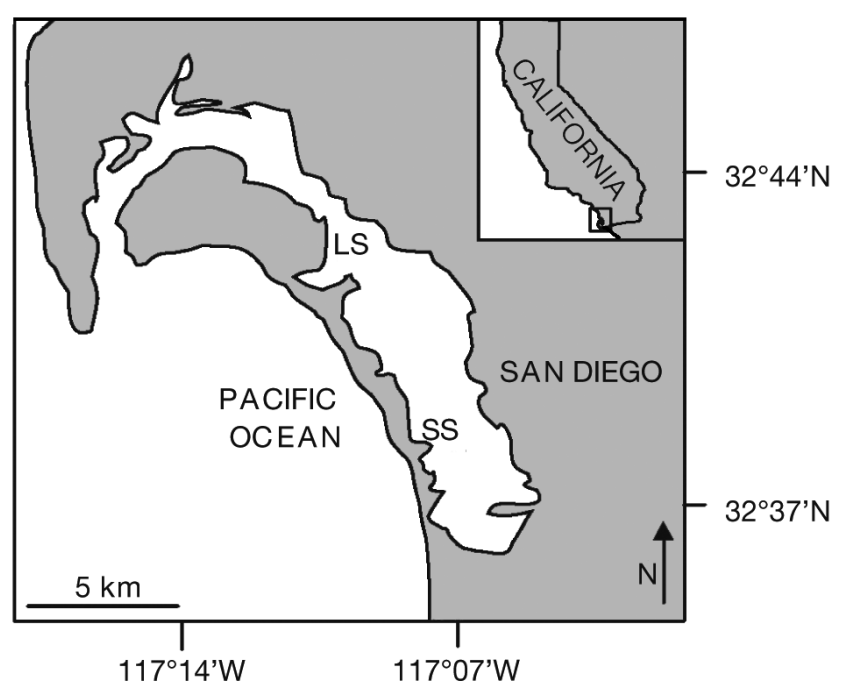

Fig. 1. Locations of small-scale (SS) and large-scale (LS) seagrass Zostera marina scarring experiments in San Diego Bay, California, USA 
Experimental design. We performed 2 separate experiments to assess how the degree of seagrass disturbance influences epifaunal density, diversity, and community composition. In both experiments we fragmented the existing eelgrass habitat by removing clumps of eelgrass habitat ('scarring' of eelgrass), but varied the spatial scale (resolution and areal extent) of the experimental plots between the 2 experiments. The small-scale scarring experiment examined how eelgrass loss and fragmentation influenced epifauna in $4 \mathrm{~m}^{2}$ areas, and the large-scale scarring experiment how eelgrass loss and fragmentation influenced epifauna in $16 \mathrm{~m}^{2}$ areas.

To establish the small-scale scarring experiment, on 12 November 2003 we established four $45 \mathrm{~m}$ transects parallel to the shoreline within a continuous eelgrass meadow at depths of ca. $3 \mathrm{~m}$. Six $2 \times 2 \mathrm{~m}$ plots were delineated along each transect by inserting rebar stakes into the sediment at plot corners; plots were no less than $5 \mathrm{~m}$ apart. The plots were then randomly assigned 1 of 6 scarring levels: $0,10,30,50,70$, and $90 \%$ eelgrass removal (Fig. 2). To ensure that initial eelgrass habitat structure did not differ among treatments before eelgrass removal, we visually divided each plot into $100,0.04 \mathrm{~m}^{2}$ cells with the aid of a gridded PVC quadrat and scored each cell for the presence or absence of eelgrass. We also counted the number of shoots in 8 randomly chosen cells in each plot. All plots began with eelgrass coverage of at least $97 \%$, and treatment groups did not differ in initial shoot densities (1-way ANOVA: $\left.F_{5,18}=0.97 ; \mathrm{p}=0.46\right)$.

\section{Experiment 1: Small-scale 'scarring'}

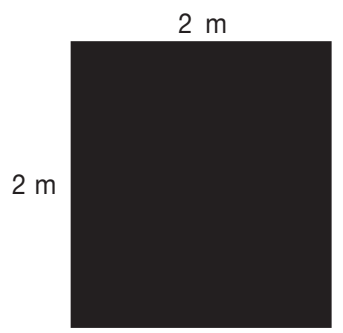

$0 \%$ (control)

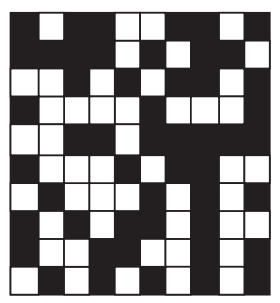

$50 \%$

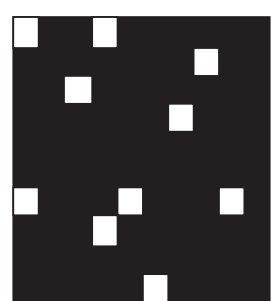

$10 \%$

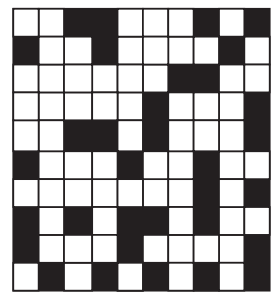

$70 \%$

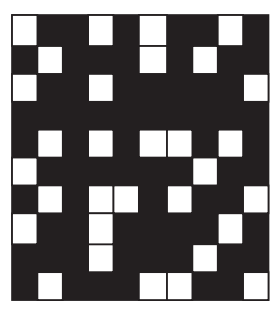

$30 \%$

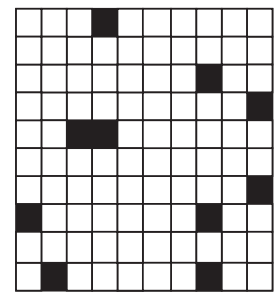

$90 \%$
Fig. 2. Zostera marina. Small-scale $\left(4 \mathrm{~m}^{2}\right.$ plots) scarring levels showing percent habitat removed. Treatment levels for the large-scale scarring exriment $\left(16 \mathrm{~m}^{2}\right.$ plots) were $0,10,50$, and $90 \%$ habitat removal
On 19 November 2003, divers scarred plots by manually removing all eelgrass shoot and rhizome material from randomly chosen cells. The plots were then sampled for epifaunal density and diversity 3 and $8 \mathrm{wk}$ after eelgrass clearing. On each sampling date, habitat cover in each plot was measured as described above to evaluate seagrass recovery. To sample epifauna, a $0.25 \mathrm{~m}^{2}$ throw-trap was deployed in a random section of each plot. The circular throw-trap was composed of a steel ring attached to a $1.6 \mathrm{~mm}$ mesh skirt. Once the throw-trap was positioned, a diver used an airpowered suction sampler to remove epifauna from the trap area for no less than $1 \mathrm{~min}$. (This technique was $96 \%$ efficient at capturing epifauna associated with both the plant tissue and the soft substrate $(<2 \mathrm{~cm}$ depth) in pilot experiments.) Samples were transported to the laboratory and placed in a freezer. Thawed samples were sorted to enumerate epifauna identified to the lowest possible taxonomic level.

To establish our large-scale scarring experiment, on 16 July 2004 we again created four $45 \mathrm{~m}$ transects in an extensive eelgrass meadow in San Diego Bay (Fig. 1). On each transect, 4 plots measuring $4 \times 4 \mathrm{~m}$ were marked and randomly assigned to 1 of 4 scarring treatments: $0,10,50$, and $90 \%$ eelgrass removal (Fig. 2). Only 4 scarring treatments were used in the large-scale experiment because of the labor-intensive nature of creating treatments at this scale. The plots were divided into $640.25 \mathrm{~m}^{2}$ cells, and each cell was visually examined to categorize coverage as bare ( 0 to 10 shoots) or vegetated ( $>10$ shoots). Complete shoot counts were also made for 8 haphazardly chosen cells per plot. Each plot had at least $98 \%$ eelgrass coverage, and treatment groups did not differ in shoot densities prior to harvesting (1-way ANOVA: $F_{3,12}=0.243 ; \mathrm{p}=0.86$ ).

On 19 and 26 July 2004 (predisturbance survey dates), eelgrass coverage in all plots was again visually assessed, and all plots were sampled for epifauna using a throw-trap and suction sampler. Pre-disturbance sampling was performed twice to determine whether similarities or differences among plots were consistent. We took 3 composite samples from random sections of each plot on each date, and no sections were sampled more than once during the entire experiment. On 9 August 2004, divers removed eelgrass from the plots by hand to create the scarring treatments. We then resampled all plots for epifauna and for eelgrass coverage 4 and $8 \mathrm{wk}$ after scarring (post-disturbance survey 
dates) and processed samples as described above for the small-scale scarring experiment.

Data analysis. For the small-scale scarring experiment, we originally intended using separate 1-way ANOVAs to correlate treatment levels with epifaunal responses. However, because the rate of seagrass regrowth was not consistent across plots, there was overlap in amounts of habitat cover between treatment levels by the first sampling date. Therefore, we used separate linear regressions to test how total epifaunal species richness, total epifaunal density, and Simpson's index of diversity $\left(D_{s}\right)$ varied with the proportional cover of eelgrass within plots. Similar to the Shannon index, $\mathrm{D}_{\mathrm{s}}$ takes into account both the number of species and their relative abundance, but is based on the biologically-relevant probability of species encounters, with larger values indicating higher probability of 2 randomly chosen individuals belonging to different species (Hurlbert 1971). We conducted separate analyses for each post-disturbance sampling date to avoid pseudoreplication (Hurlbert 1984). The assumptions of randomly distributed residuals and linearity were checked visually with standardized residual plots.

For the large-scale scarring experiment, we first ran a multivariate analysis of variance (MANOVA) to test for differences in overall faunal community characteristics among the 4 levels of eelgrass removal. A separate MANOVA was used for each sampling date. We then used separate 1-way ANOVAs for each sampling date to test if total epifaunal species richness, total epifaunal density, and epifaunal diversity differed among levels of eelgrass removal. Prior to performing all tests, we visually evaluated probability plots to test that data were normally distributed and used Cochran's $C$-test to test for heterogeneity of variances (Underwood 1997). Data were transformed where necessary to meet the assumptions of the statistical procedures.

For both the small-scale and large-scale experiments, epifaunal community composition was evaluated on each sampling date using multivariate statistical techniques included in the PRIMER software package (Clarke 1993). Following square-root transformation of species abundance data, Bray-Curtis similarity values between all samples were calculated and illustrated using non-metric multidimensional scaling (MDS) ordination techniques, which map samples in 2-dimensional space so that samples similar in species composition are close together, while dissimilar samples are farther apart (Clarke \& Warwick 1994). All MDS ordinations had stress levels $<0.2$. We tested whether community composition varied among levels of habitat loss using a 1-way analysis of similarity (ANOSIM). If differences in community composition were evident, we used similarity percentage tests (SIMPER) to determine which spe- cies were driving these epifaunal community changes (Clarke \& Warwick 1994).

\section{RESULTS}

\section{Small-scale eelgrass scarring}

We found 27 invertebrate and 1 fish species (the arrow goby Clevelandia ios) in suction samples for our small-scale scarring experiment (Table 1), with 874 and 884 individuals collected in Weeks 3 and 8, respectively; 3 species accounted for over half of the epifaunal abundance in this experiment: the bivalves Macoma spp. (28\%) and Musculista senhousia (17\%) and the shrimp Hippolyte californica (11\%).

Eelgrass coverage $3 \mathrm{wk}$ after habitat removal ranged from 12 to $100 \%$, but there were no linear or non-linear correlations between percent eelgrass cover and species richness, total epifaunal density, or $\mathrm{D}_{\mathrm{s}}$ (Table 2, Fig. 3). Eelgrass cover ranged from 17 to $97 \% 8 \mathrm{wk}$ after removal, but again we found no significant linear or non-linear correlations between habitat cover and species richness, total epifaunal density or $\mathrm{D}_{\mathrm{s}}$ (Table 2, Fig. 3).

Species assemblages in plots did not change in response to small-scale eelgrass scarring (Fig. 4). MDS ordinations resulted in tight clustering of all samples regardless of the amount of remaining habitat cover in the plots. ANOSIM tests supported this lack of differentiation on both Week $3(\mathrm{p}=0.313)$ and Week $8(\mathrm{p}=$ 0.962) sampling dates.

\section{Large-scale eelgrass scarring}

We found 37 invertebrate species and 6 fish species in suction samples for our large-scale scarring experiment (Table 1), with 7246 individuals collected before eelgrass removal, and 2699 and 3545 individuals collected 4 and 8 wk after removal, respectively. The shrimp Hippolyte californica comprised $27 \%$ of the total abundance in this experiment, followed by the isopod Paracerceis sculpta (19\%), the bivalve Musculista senhousia (18\%), and the gastropod Nassarius tegula $(11 \%)$. After eelgrass removal, differences in habitat cover between treatment levels persisted throughout the experiment (Table 3).

The MANOVA on the combined faunal community characteristics indicated that there was no difference among plots before eelgrass disturbance (Wilks' lambda: 19 July: $F_{9,24}=0.783, p=0.634 ; 26$ July: $F_{9,24}=$ $0.806, \mathrm{p}=0.615)$, but the $90 \%$ removal treatment differed from the 0,10 , and $50 \%$ removal treatments both $4 \mathrm{wk}\left(F_{9,24}=5.865, \mathrm{p}<0.001\right)$ and $8 \mathrm{wk}\left(F_{9,24}=3.332\right.$, 
Table 1. Epifaunal species' densities in the small-scale and large-scale scarring experiments in Zostera marina beds

\begin{tabular}{|c|c|c|c|c|c|c|}
\hline \multirow{2}{*}{ Species } & \multicolumn{2}{|c|}{ Small-scale experiment } & \multicolumn{2}{|c|}{ Large-scale experiment } & \multirow{2}{*}{ Total abundance } & \multirow[t]{2}{*}{$\%$ of total } \\
\hline & Abundance & $\%$ & Abundance & $\%$ & & \\
\hline Hippolyte californica & 192 & 10.9 & 3592 & 26.6 & 3784 & 24.82 \\
\hline Musculista senhousia & 291 & 16.6 & 2445 & 18.1 & 2736 & 17.94 \\
\hline Paracerceis sculpta & 86 & 4.9 & 2516 & 18.7 & 2602 & 17.06 \\
\hline Nassarius tegula & 104 & 5.9 & 1505 & 11.2 & 1609 & 10.55 \\
\hline Lyonsia californica & 130 & 7.4 & 809 & 6.0 & 939 & 6.16 \\
\hline Macoma spp. & 485 & 27.6 & 294 & 2.2 & 779 & 5.11 \\
\hline Nassarius perpinguis & 0 & 0.0 & 454 & 3.4 & 454 & 2.98 \\
\hline Gammaridea spp. & 138 & 7.8 & 250 & 1.9 & 388 & 2.54 \\
\hline Notoacmea depicta & 16 & 0.9 & 238 & 1.8 & 254 & 1.67 \\
\hline Serolis carinata & 32 & 1.8 & 221 & 1.6 & 253 & 1.66 \\
\hline Bulla gouldiana & 2 & 0.1 & 211 & 1.6 & 213 & 1.40 \\
\hline Laevicardium substratum & 0 & 0.0 & 202 & 1.5 & 202 & 1.32 \\
\hline Clevelandia ios & 28 & 1.6 & 173 & 1.3 & 201 & 1.32 \\
\hline Mitrella carnita & 2 & 0.1 & 188 & 1.4 & 190 & 1.25 \\
\hline Tellina spp. & 103 & 5.9 & 10 & 0.1 & 113 & 0.74 \\
\hline Ophiuoidea & 93 & 5.3 & 16 & 0.1 & 109 & 0.71 \\
\hline Lophopanopeus bellus & 5 & 0.3 & 69 & 0.5 & 74 & 0.49 \\
\hline Acteocina inculta & 0 & 0.0 & 65 & 0.5 & 65 & 0.43 \\
\hline Alpheus californiensis & 14 & 0.8 & 40 & 0.3 & 54 & 0.35 \\
\hline Crucibulum spinosum & 1 & 0.1 & 25 & 0.2 & 26 & 0.17 \\
\hline Pyromaia tuberculata & 1 & 0.1 & 23 & 0.2 & 24 & 0.16 \\
\hline Pandalus spp. & 0 & 0.0 & 22 & 0.2 & 22 & 0.14 \\
\hline Chione undatella & 3 & 0.2 & 18 & 0.1 & 21 & 0.14 \\
\hline Paranthura elegans & 3 & 0.2 & 17 & 0.1 & 20 & 0.13 \\
\hline Syngnathus leptorhynchus & 0 & 0.0 & 18 & 0.1 & 18 & 0.12 \\
\hline Navanax inermis & 0 & 0.0 & 12 & 0.1 & 12 & 0.08 \\
\hline Heterostichus rostratus & 0 & 0.0 & 11 & 0.1 & 11 & 0.07 \\
\hline Solen rosaceus & 6 & 0.3 & 4 & $<0.1$ & 10 & 0.07 \\
\hline Styela truncata & 10 & 0.6 & 0 & 0.0 & 10 & 0.07 \\
\hline Heptacarpus spp. & 5 & 0.3 & 3 & $<0.1$ & 8 & 0.05 \\
\hline Syngnathus arctus & 0 & 0.0 & 8 & 0.1 & 8 & 0.05 \\
\hline Crepidula norrisiarum & 0 & 0.0 & 7 & 0.1 & 7 & 0.05 \\
\hline Aequipecten aequisulcatus & 0 & 0.0 & 5 & $<0.1$ & 5 & 0.03 \\
\hline Ostrea lurida & 0 & 0.0 & 4 & $<0.1$ & 4 & 0.03 \\
\hline Crangon spp. & 3 & 0.2 & 0 & 0.0 & 3 & 0.02 \\
\hline Hemigrapsus oregonensis & 0 & 0.0 & 3 & $<0.1$ & 3 & 0.02 \\
\hline Hypsoblennius gentilis & 0 & 0.0 & 3 & $<0.1$ & 3 & 0.02 \\
\hline Caprella spp. & 2 & 0.1 & 0 & 0.0 & 2 & 0.01 \\
\hline Pagurus spp. & 0 & 0.0 & 2 & $<0.1$ & 2 & 0.01 \\
\hline Epitonium tinctum & 0 & 0.0 & 1 & $<0.1$ & 1 & 0.01 \\
\hline Mactra californica & 0 & 0.0 & 1 & $<0.1$ & 1 & 0.01 \\
\hline Naushonia macginitiei & 1 & 0.1 & 0 & 0.0 & 1 & 0.01 \\
\hline Octopus bimaculatus & 0 & 0.0 & 1 & $<0.1$ & 1 & 0.01 \\
\hline Portunus xantusii & 0 & 0.0 & 1 & $<0.1$ & 1 & 0.01 \\
\hline Pugettia gragilus & 1 & 0.1 & 0 & 0.0 & 1 & 0.01 \\
\hline Paraclinnus integripinnis & 0 & 0.0 & 1 & $<0.1$ & 1 & 0.01 \\
\hline Tegelus californianus & 1 & 0.1 & 0 & 0.0 & 1 & 0.01 \\
\hline Terebra danai & 0 & 0.0 & 1 & $<0.1$ & 1 & 0.01 \\
\hline Urolophus halleri & 0 & 0.0 & 1 & $<0.1$ & 1 & 0.01 \\
\hline Total abundance & 1758 & & 13490 & & 15248 & \\
\hline
\end{tabular}

$\mathrm{p}=0.009)$ after disturbance. For the univariate ANOVAs, species richness did not differ among treatments before eelgrass disturbance, but plots with $90 \%$ eelgrass removal had significantly lower species richness than plots with 0,10 , and $50 \%$ habitat removal 4 and $8 \mathrm{wk}$ after the initial disturbance (Fig. 5, Table 4). Plots with $90 \%$ eelgrass removal had approximately half the number of species of plots in all other treat- ments. Although not significant, there was a trend for $10 \%$ removal plots to have higher numbers of species than 0 and $50 \%$ plots 4 and 8 wk after harvesting.

Similar to species richness, mean total epifaunal density did not differ among treatments before eelgrass disturbance, but plots with $90 \%$ eelgrass removal had significantly lower mean total epifaunal density than did plots with 0,10 , and $50 \%$ eelgrass removal 4 and 8 wk 
Table 2. Zostera marina. Results of linear regression analyses for the small-scale scarring experiment 3 and 8 wk after eelgrass disturbance

\begin{tabular}{|lccccc|}
\hline \multirow{2}{*}{ Variable } & \multicolumn{4}{c|}{ Time since disturbance } \\
\cline { 2 - 5 } & $\mathrm{r}^{2}$ & $\mathrm{wk}-\mathrm{p}$ & & $\mathrm{r}^{2}$ & $\mathrm{wk}$ \\
\hline Species richness & 0.016 & 0.555 & 0.005 & 0.740 \\
Epifaunal density & 0.001 & 0.983 & 0.021 & 0.507 \\
Simpson's index of diversity $\left(\mathrm{D}_{\mathrm{s}}\right)$ & 0.113 & 0.109 & 0.009 & 0.663 \\
\hline
\end{tabular}

ilar epifaunal community composition before eelgrass disturbance (ANOSIM; 19 July: $p=0.830 ; 26$ July: $p=0.800)$, but there were dramatic differences in community composition between the $90 \%$ removal plots and all other plots 4 wk $(p=0.013)$ and $8 \mathrm{wk}(\mathrm{p}=0.004)$ after the initial disturbance. Furthermore, within treatment groups, $90 \%$ removal plots had lower species similarity values than other treatment levels (data not shown).

after harvesting (Fig. 5, Table 4). Plots with $90 \%$ eelgrass removal had approximately one-quarter of the total epifaunal density of plots in all other treatments. We found no significant difference in $\mathrm{D}_{\mathrm{s}}$ among treatments before or after eelgrass harvesting (Table 4, Fig. 5).

Species composition in experimental plots shifted in response to habitat loss (Fig. 6). All treatments had sim-
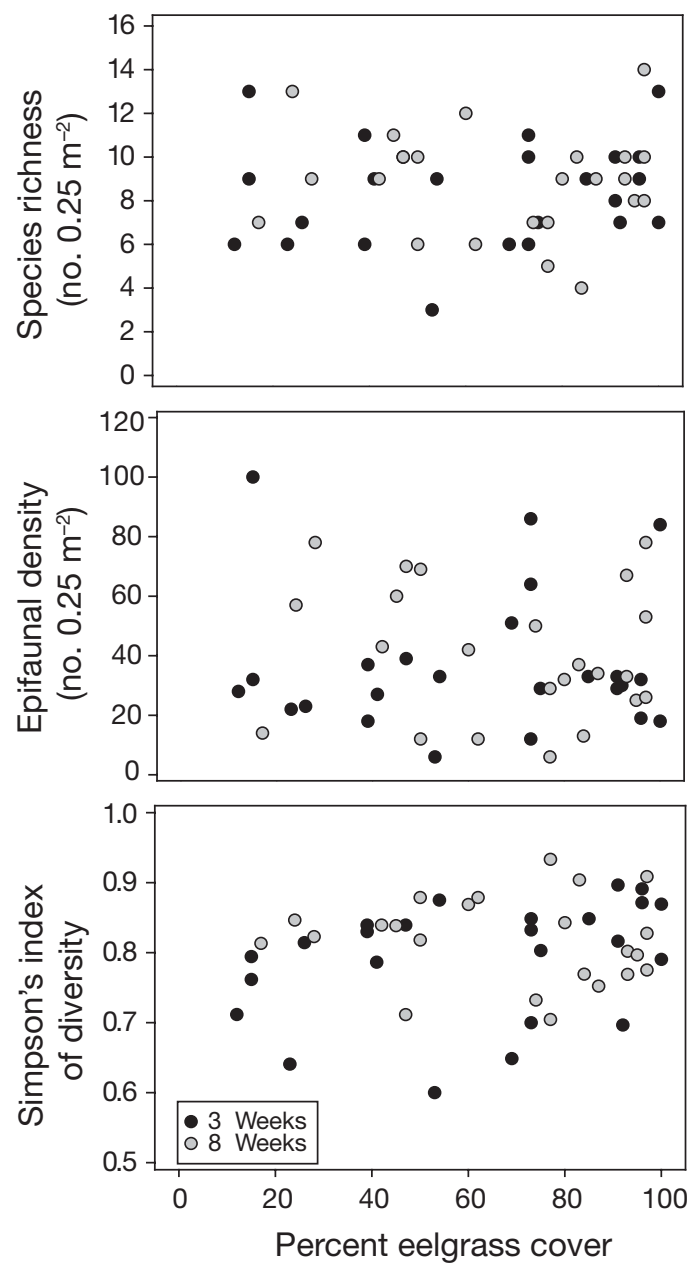

Fig. 3. Zostera marina. Number of species, total epifaunal density, and Simpson's index of diversity $\left(D_{s}\right)$ vs. percent eelgrass cover 3 and 8 wk after initial disturbance in the smallscale scarring experiment
SIMPER tests revealed that 4 species chiefly contributed to dissimilarities among treatments: Musculista senhousia, Nassarius tegula, Paracerceis sculpta, and Hippolyte californica, all of which were less abundant in $90 \%$ removal plots than in the remaining plots.

\section{DISCUSSION}

Previous studies have demonstrated that epifaunal survival (Irlandi et al. 1995, Irlandi 1997), density (Hovel \& Lipcius 2002), and diversity (Frost et al. 1999, Healey \& Hovel 2004) differ among existing seagrass landscapes that vary in habitat cover and configuration. Our study attempted to experimentally evaluate how seagrass disturbance resulting in habitat loss and fragmentation alters epifaunal density, diversity, and community composition, and to evaluate the influence of spatial scale on disturbance impacts. We found that high levels

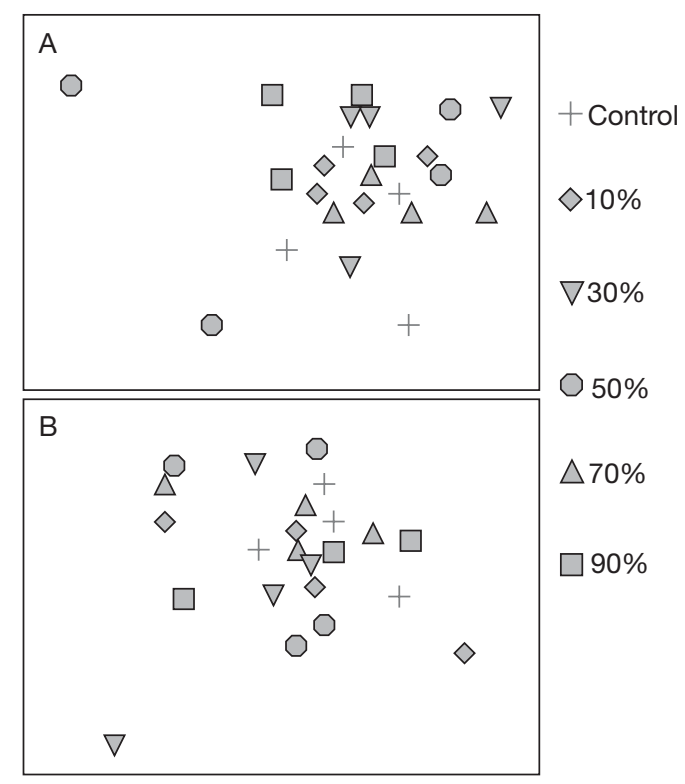

Fig. 4. Zostera marina. MDS ordinations of treatment plots in the small-scale scarring experiment at (A) $3 \mathrm{wk}$ and (B) $8 \mathrm{wk}$ after eelgrass clearing (symbols represent percent habitat removal). Stress values for all ordinations are $<0.20$ 
Table 3. Zostera marina. Mean $( \pm 1 \mathrm{SE})$ percent cover in treatment plots before and after disturbance for the large-scale scarring experiment in 2004

\begin{tabular}{|lcccc|}
\hline \multirow{2}{*}{ Treatment } & \multicolumn{2}{c}{ Pre-disturbance } & \multicolumn{2}{c|}{ Post-disturbance } \\
& 19 Jul & 26 Jul & 6 Sep & 4 Oct \\
\hline Control & $100(0)$ & $100(0)$ & $100(0)$ & $96.1(2.34)$ \\
$10 \%$ & $100(0)$ & $100(0)$ & $87.12(0.98)$ & $83.98(3.02)$ \\
$50 \%$ & $99.62(0.39)$ & $99.62(0.39)$ & $51.17(1.95)$ & $56.64(1.33)$ \\
$90 \%$ & $99.62(0.39)$ & $99.62(0.39)$ & $14.45(2.06)$ & $18.75(1.43)$ \\
\hline
\end{tabular}
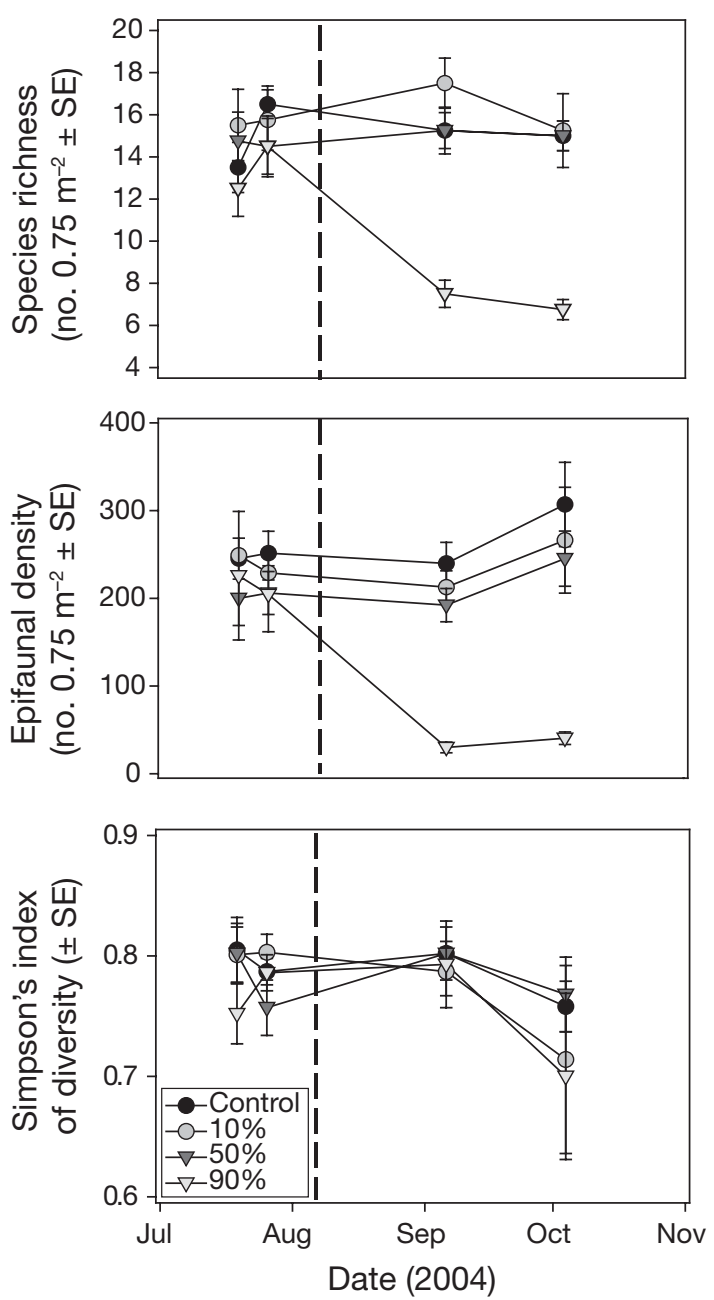

Fig. 5. Zostera marina. Mean $( \pm \mathrm{SE})$ number of species, epifaunal density, and Simpson's index of diversity $\left(D_{s}\right)$ in treatment plots on pre-disturbance (Weeks 1 and 2) and postdisturbance (Weeks 8 and 12) sampling dates in the largescale scarring experiment. Dashed line represents date of experimental eelgrass scarring

of eelgrass habitat loss reduced epifaunal species richness and total epifaunal density, and altered epifaunal community composition, but only when the scale of habitat removal was relatively large. Changes to the epifaunal community were only evident when $>50 \%$ of the eelgrass habitat was removed, suggesting that a threshold level of eelgrass loss exists beyond which eelgrass habitat function declines rapidly.

\section{Habitat loss thresholds}

Habitat disturbance results in habitat loss and in habitat fragmentation (i.e. the breaking apart of habitat), both of which may alter faunal communities (Fahrig 2003). At ca. 50 to $80 \%$ habitat loss, these 2 processes may synergistically act to disrupt critical pathways of habitat connectivity, resulting in dramatic reductions in habitat function and population persistence (Turner 1989, Andrén 1994, With \& Crist 1995). Movement rates of tenebrionid beetles in experimental microlandscapes declined dramatically when ca. $80 \%$ of the habitat was removed (Wiens et al. 1997), and grasshopper rates of travel were sharply reduced after $65 \%$ of grassland habitat was removed (With \& Crist 1995). Likewise, sharp declines in several songbird populations occurred only after ca. $80 \%$ of forest cover was lost (Villard et al. 1999).

In our large-scale eelgrass scarring experiment, plots in which $90 \%$ of the habitat was removed showed drastically reduced species richness and total epifaunal density compared to plots with 0,10 , or $50 \%$ habitat loss. In addition, these reductions in the epifaunal communities were evident up to $8 \mathrm{wk}$ after harvesting. Thus, organisms may not only have been affected by the initial physical disturbance caused by habitat removal (sediment raking and shoot displacement), but also by effects of the remaining eelgrass cover and configuration on ecological processes. Similar results were found in an evaluation of the effects of trampling intensity on seagrass epifauna in Puerto Rico (Eckrich \& Holmquist 2000). Although seagrass loss occurred at all trampling levels, only extremely high levels of habitat degradation caused decreases in shrimp densities. Additionally, the density of fishes and shrimp in propeller scarred seagrass beds in Florida did not decline when up to 31 and $50 \%$, respectively, of the seagrass habitat was scarred (Bell et al. 2002).

Although more data points between 50 and $90 \%$ habitat removal would be necessary to better pinpoint a threshold level of eelgrass loss for epifauna, it appears that at the scale of our large plots, removal of up to $50 \%$ of the habitat will have little effect on epifaunal density, diversity, and community composition. With the exception of the $90 \%$ habitat removal plots, organisms in denuded sections simply may have moved into remaining vegetated sections of the microlandscape, leaving species richness and total epifaunal density unchanged. Epifaunal organisms may 
Table 4. Zostera marina. Results of 1-way ANOVAs for epifaunal response variables on pre- and post-disturbance sampling dates for the large-scale scarring experiment. *Significant at $\mathrm{p}<0.05$

\begin{tabular}{|c|c|c|c|c|c|c|c|c|c|c|c|c|}
\hline \multirow{2}{*}{ Source of variation } & \multicolumn{4}{|c|}{ Species richness } & \multicolumn{4}{|c|}{ Total epifaunal density } & \multicolumn{4}{|c|}{ Simpson's index of diversity } \\
\hline & $\mathrm{df}$ & MS & $F$ & $\mathrm{p}$ & $\mathrm{df}$ & $\mathrm{MS}$ & $F$ & $\mathrm{p}$ & df & MS & $F$ & $\mathrm{p}$ \\
\hline \multicolumn{13}{|l|}{ Pre-disturbance } \\
\hline \multicolumn{13}{|l|}{19 Jul 2004} \\
\hline Removal level & 3 & 7.062 & 0.885 & 0.476 & 3 & 2015.500 & 0.292 & 0.831 & 3 & 0.003 & 1.000 & 0.426 \\
\hline Residual & 12 & 7.979 & 12 & 6906.500 & 12 & 0.003 & & & & & & \\
\hline \multicolumn{13}{|l|}{26 Jul 2004} \\
\hline Removal level & 3 & 3.896 & 0.586 & 0.636 & 3 & 1972.300 & 0.636 & 0.606 & 3 & 0.001 & 1.350 & 0.305 \\
\hline Residual & 12 & 6.646 & 12 & 3103.500 & 12 & 0.001 & & & & & & \\
\hline \multicolumn{13}{|l|}{ Post-disturbance } \\
\hline \multicolumn{13}{|l|}{6 Sep 2004} \\
\hline Removal level & 3 & 76.750 & 20.242 & $<0.001^{*}$ & 3 & 35707.729 & 27.047 & $<0.001^{*}$ & 3 & 0.000 & 0.100 & 0.958 \\
\hline Residual & 12 & 3.792 & 12 & 1320.187 & 12 & 0.002 & & & & & & \\
\hline \multicolumn{13}{|l|}{4 Oct 2004} \\
\hline Removal level & 3 & 69.500 & 16.194 & $<0.001^{*}$ & 3 & 56607.500 & 8.105 & $0.003^{*}$ & 3 & 0.004 & 0.355 & 0.787 \\
\hline Residual & 12 & 4.292 & 12 & 6984.042 & 12 & 0.012 & & & & & & \\
\hline
\end{tabular}

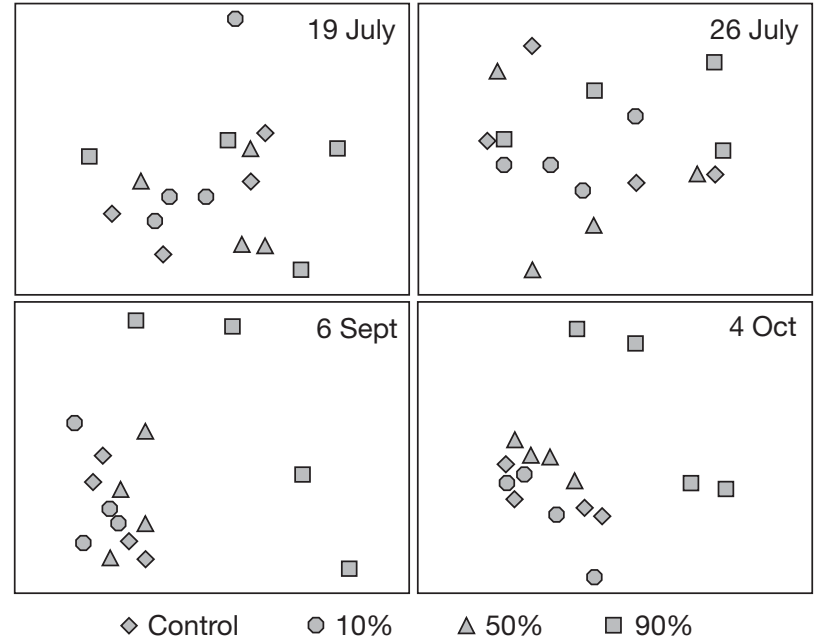

Fig. 6. Zostera marina. MDS ordinations of Bray-Curtis similarity values for treatment plots on pre-disturbance (19 and 26 July 2004) and post-disturbance (6 September and 4 October 2004) sampling dates in large-scale scarring experiment (symbols represent habitat removal). Stress values for all ordinations are $<0.20$

also have utilized unvegetated sediment within plots to forage or simply to move among vegetated patches. This was the case, for example, for red-backed voles Clethrionomys gapperi which did not avoid clear-cut areas of forest if the overall landscape was still dominated by forest habitat (Hayward et al. 1999). Similarly, and in contrast to predictions of theoretical models, movement behavior of large crickets was not influenced by habitat loss in experimental microlandscapes, because crickets easily moved over unvegetated areas (With et al. 1999).
In contrast to our large-scale plots, we found no effect of eelgrass disturbance on epifauna in our smallscale scarring experiment. Epifaunal responses to habitat loss may have been dampened because our experimental plots were embedded within an extensive eelgrass meadow. Wiens (1976) suggests that organismal responses to habitat patchiness will depend on the scale (areal extent and resolution) at which they perceive their surroundings. In our small-scale scarring experiment, plots with $90 \%$ habitat loss were dominated by unvegetated sediment, but epifaunal organisms may have perceived these bare areas as small perforations in a continuous eelgrass habitat rather than as an unsuitable matrix habitat.

Surprisingly, $\mathrm{D}_{\mathrm{s}}$ did not decrease with increasing habitat loss in either experiment. This is probably due to high loss rates of dominant species such as Musculista senhousia (Asian mussels), Paracerceis sculpta (isopod), and Hippolyte californica (grass shrimp). Thus, although species richness declined, large effects of habitat loss on dominant species caused community evenness to increase. Uhrin \& Holmquist (2003) documented similar reductions in species dominance coupled with lower species numbers and abundances within eelgrass areas scarred by boat propellers. SIMPER results illustrate that declines in these species' abundances within $90 \%$ habitat removal plots caused noticeable shifts in species composition and a high dissimilarity among replicate plots. For example, after seagrass disturbance the gastropod Nassarius tegula heavily recolonized one plot, but was rare or absent in the other $90 \%$ habitat removal plots. Our results are consistent with those of past studies that have shown increased variability among samples in highly impacted sites (Warwick \& Clarke 1993), and suggest 
that once many individuals of the dominant species are lost, it is difficult to predict which taxa will colonize plots. Researchers should be cautious of using diversity indices as the sole benchmark for assessing the biological impact of habitat disturbance and degradation.

Some caution should be exercised in extrapolating these findings to other spatial scales, locations, and seagrass communities. First, our experiments were performed at relatively small scales at 2 locations in San Diego Bay over a relatively short time period. More studies are needed in a variety of locations and at a variety of scales to better determine how epifaunal communities respond to habitat disturbance in seagrass. Second, we quantified short-term responses of epifauna to eelgrass removal, and it is likely that in heavily scarred areas epifaunal density and diversity would return to pre-disturbance levels once eelgrass regrowth was complete.

\section{Effects of seagrass loss and fragmentation on epifauna}

The effects of seagrass habitat loss and fragmentation on faunal abundance, survival and diversity appear to be inconsistent among taxa, regions, and through time (reviewed by Bell et al. 2001). For instance, juvenile blue crab Callinectes sapidus survival was inversely correlated with eelgrass patch size in late spring, but not in late summer (Hovel \& Lipcius 2001). Additionally, components of seagrass landscape structure dictating juvenile crab survival differed between North Carolina and California seagrass beds (Hovel 2003). Inconsistencies in the effects of seagrass habitat loss and fragmentation on fauna may largely be due to confounding of landscape structure with hydrodynamic regime, patch age, and seagrass structural complexity (e.g. shoot density, length, or biomass), which may strongly influence faunal abundance, survival, and community composition (Fonseca \& Kenworthy 1987, Orth 1992). In North Carolina seagrass beds, seasonal epifaunal densities were primarily correlated with seagrass shoot biomass and hydrodynamic regime rather than with seagrass landscape structure (Hovel et al. 2002). Survival of the infaunal bivalve Mercenaria mercenaria increased with increasing seagrass landscape cover, but when seagrass shoot density and belowground biomass were standardized between patch sizes using artificial seagrass, survival did not differ between 2 and $16 \mathrm{~m}^{2}$ plots (Irlandi 1997).

By experimentally disturbing plots within a continuous seagrass landscape, we removed confounding factors such as seagrass landscape structure, structural complexity, hydrodynamic regime, and time since habitat removal. This technique also allowed us to evaluate the effect of the initial disturbance on the epifaunal community. However, the labor-intensive nature of removing seagrass habitat from plots limited the scale and number of habitat removal treatments we were able to use. We suggest that, whenever possible, future studies on effects of seagrass habitat fragmentation and loss combine large-scale experiments that span landscapes or existing patches, with smaller-scale experiments incorporating controlled disturbances that standardize potentially confounding factors.

\section{Conservation implications}

In addition to serving as a model system for landscape ecology studies, understanding the impact of seagrass disturbance on epifaunal species is imperative for resource managers and policy makers. Seagrass beds are primarily found in shallow bays and estuaries, making them especially susceptible to human activities. Physical disturbance to seagrass beds can have both direct and indirect impacts on the plant and its associated community. Damage from vessels and other sources can directly decrease seagrass shoot and rhizome densities. Although dependent on the type and intensity of disturbance, seagrass species may require 1 to $5 \mathrm{yr}$ to recover from these physical disturbances (Zieman 1976, Rasheed 1999). Longerterm, indirect impacts from physical damage may include decreases in primary and secondary biological production, destabilization of sediments, and reductions in water clarity (Fonseca et al. 1998).

In southern California, federal policy requires mitigation for seagrass habitat loss caused by construction and other activities that disturb seagrass habitats (National Marine Fisheries Service 1991). Seagrass shoot transplantation is the most common form of mitigation conducted when damage to seagrass habitat occurs. However, some projects may be exempt from this requirement, if $<10 \mathrm{~m}^{2}$ of eelgrass are disturbed. In addition, impacts such as propeller scarring and anchor damage are not explicitly regulated under the policy. Our results suggest that intense, localized habitat loss drastically decreases epifaunal species richness and abundance. Resource managers should be cautious of allowing activities which may cumulatively cause seagrass disturbances analogous to our largescale, $90 \%$ habitat removal plots.

Acknowledgements. This study was funded by a grant to K.A.H. from the Unified Port of San Diego and to B.J.R. from the PADI Project Aware Foundation. We thank J. Franklin, C. D. Lin, and 4 anonymous reviewers for helpful comments on the manuscript. We are especially grateful to L. Sirota, D. Healey, T. Mai, R. Kushner, and D. Lipski for field assistance. 


\section{LITERATURE CITED}

Allen LG, Findlay AM, Phalen CM (2002) Structure and standing stock of the fish assemblages of San Diego Bay, California from 1994 to 1999. Bull South Calif Acad Sci 101:49-85

Andrén H (1994) Effects of habitat fragmentation on birds and mammals in landscapes with different proportions of suitable habitat: a review. Oikos 71:355-366

Bell SS, Brooks RA, Robbins BD, Fonseca MS, Hall MO (2001) Faunal response to fragmentation in seagrass habitats: implications for seagrass conservation. Biol Conserv 100: 115-123

Bell SS, Hall MO, Soffian S, Madley K (2002) Assessing the impact of boat propeller scars on fish and shrimp utilizing seagrass beds. Ecol Appl 12:206-217

Bologna PAX, Heck KL (1999) Differential predation and growth rates of bay scallops within a seagrass habitat. J Exp Mar Biol Ecol 239:299-314

Clarke K (1993) Non-parametric multivariate analysis of changes in community structure. Aust J Ecol 18:117-143

Clarke K, Warwick RM (1994) Change in marine communities: an approach to statistical analysis and interpretation. Natural Environment Research Council, Swindon

Creed JC, Amado Filho GM (1999) Disturbance and recovery of the macroflora of a seagrass (Halodule wrightii) meadow in the Abrolhos Marine National Park, Brazil: an experimental evaluation of anchor damage. J Exp Mar Biol Ecol 235:285-306

Diffendorfer JE, Gaines MS, Holt RD (1995) Habitat fragmentation and movements of three small mammals (Sigmodon, Microtus, and Peromyscus). Ecology 76: 827-839

Eckrich CE, Holmquist JG (2000) Trampling in a seagrass assemblage: direct effects, response of associated fauna, and the role of substrate characteristics. Mar Ecol Prog Ser 201:199-209

Fahrig L (1997) Relative effects of habitat loss and fragmentation on population extinction. J Wildl Manag 61:603-610

Fahrig L (2003) Effects of habitat fragmentation on biodiversity. Annu Rev Ecol Syst 34:487-515

Fonseca MS, Kenworthy WJ (1987) Effects of current on photosynthesis and distribution of seagrasses. Aquat Bot 27:59-78

Fonseca MS, Kenworthy WJ, Thayer GW (1998) Guidelines for the conservation and restoration of seagrasses in the United States and adjacent waters. NOAA's Coastal Ocean Program, Silver Springs, MD

Frost MT, Rowden AA, Attrill MJ (1999) Effect of habitat fragmentation on the macroinvertebrate infaunal communities associated with the seagrass Zostera marina L. Aquat Conserv Mar Freshw Ecosyst 9:255-263

Hayward GD, Henry AH, Ruggiero LF (1999) Response of red-backed voles to recent patch cutting in subalpine forest. Conserv Biol 13:168-176

Healey D, Hovel KA (2004) Seagrass bed patchiness: effects on epifaunal communities in San Diego Bay, USA. J Exp Mar Biol Ecol 313:155-174

Hemminga MA, Duarte CM (2000) Seagrass ecology. Cambridge University Press, Cambridge

Hovel KA (2003) Habitat fragmentation in marine landscapes: relative effects of habitat cover and configuration on juvenile crab survival in California and North Carolina seagrass beds. Biol Conserv 110:401-412

Hovel KA, Lipcius RN (2001) Habitat fragmentation in a seagrass landscape: patch size and complexity control blue crab survival. Ecology 82:1814-1829
Hovel KA, Lipcius RN (2002) Effects of seagrass habitat fragmentation on juvenile blue crab survival and abundance. J Exp Mar Biol Ecol 271:75-98

Hovel KA, Fonseca MS, Myer DL, Kenworthy WJ, Whitfield PE (2002) Effects of seagrass landscape structure, structural complexity and hydrodynamic regime on macrofaunal densities in North Carolina seagrass beds. Mar Ecol Prog Ser 243:11-24

Hurlbert SH (1971) The nonconcept of species diversity: a critique and alternate parameters. Ecology 52:577-586

Hurlbert SH (1984) Pseudoreplication and the design of ecological field experiments. Ecol Monogr 54:187-211

Irlandi EA (1994) Large- and small-scale effects of habitat structure on rates of predation: how percent coverage of seagrass affects rates of predation and siphon nipping on an infaunal bivalve. Oecologia 98:176-183

Irlandi EA (1996) The effects of seagrass patch size and energy regime on growth of a suspension-feeding bivalve. J Mar Res 54:161-185

Irlandi EA (1997) Seagrass patch size and survivorship of an infaunal bivalve. Oikos 78:511-518

Irlandi EA, Ambrose WGL, Orlando BA (1995) Landscape ecology and the marine environment: how spatial configuration of seagrass habitat influences growth and survival of the bay scallop. Oikos 72:307-313

Irlandi EA, Orlando BA, Ambrose WG Jr (1999) Influence of seagrass habitat patch size on growth and survival of juvenile bay scallops, Argopectin irradians concentritus (Say). J Exp Mar Biol Ecol 235:21-43

Laurance WF, Ferriera LV, Rankin-de Merona JM, Laurance SG (1998) Rain forest fragmentation and the dynamics of Amazonian tree communities. Ecology 79:2032-2040

McGarigal K, Cushman SA (2002) Comparative evaluation of experimental approaches to the study of habitat fragmentation effects. Ecol Appl 12:335-345

National Marine Fisheries Service (1991) Southern California eelgrass mitigation policy. National Marine Fisheries Service, Long Beach, CA

Orth RJ (1992) A perspective on plant-animal interactions in seagrasses: physical and biological determinants influencing plant and animal abundance. In: John DM, Hawkins SJ, Price JH (eds) Plant-animal interactions in the marine benthos. Systematics Assoc Spec Vol 46, Clarendon Press, Oxford, p 147-164

Orth RJ, Heck KL Jr, van Montfrans J (1984) Faunal communities in seagrass beds: a review of the influence of plant structure and prey characteristics on predator-prey relationships. Estuaries 7:339-350

Parker M, MacNally R (2002) Habitat loss and the habitat fragmentation threshold: an experimental evaluation of impacts on richness and total abundances using grassland invertebrates. Biol Conserv 105:217-229

Peterson C (1986) Enhancement of Mercenaria mercenaria densities in seagrass beds: is pattern fixed during settlement season or altered by subsequent differential survival? Limnol Oceanogr 31:200-205

Pile A, Lipcius RN, van Montfrans J, Orth RJ (1996) Densitydependent settle-recruit-juvenile relationships in blue crabs. Ecol Monogr 66:277-300

Rasheed MA (1999) Recovery of experimentally created gaps within tropical Zostera capricorni seagrass meadow, Queensland, Australia. J Exp Mar Biol Ecol 235:183-200

Reusch TBH, Williams SL (1999) Macrophyte canopy structure and the success of an invasive marine bivalve. Oikos 84:398-416

Sargent F, Leary D, Crewz D, Kreuer C (1995) Scarring of Florida's seagrasses: assessment and management options. 
Fla Mar Res Inst Tech Rep TR-1, Florida Marine Research Institute, St. Petersburg, FL

Townsend E, Fonseca MS (1998) Bioturbation as a potential mechanism influencing spatial heterogeneity of North Carolina seagrass beds. Mar Ecol Prog Ser 169:123-132

Turner MG (1989) Landscape ecology: the effect of pattern on process. Annu Rev Ecol Syst 20:171-197

Turner SJ, Hewitt JE, Wilkinson MR, Morrissey DJ, Thrush SF, Cummings VJ, Funnell G (1999) Seagrass patches and landscapes: the influence of wind-wave dynamics and hierarchical arrangements of spatial structure on macrofaunal seagrass communities. Estuaries 22:1016-1032

Uhrin AV, Holmquist JG (2003) Effects of propeller scarring on macrofaunal use of the seagrass Thalassia testudinum. Mar Ecol Prog Ser 250:62-70

Underwood AJ (1997) Experiments in ecology. Cambridge University Press, Cambridge

Villard MA, Trzcinski MK, Merriam G (1999) Fragmentation effects on forest birds: relative influence of woodland cover and configuration on landscape occupancy. Conserv Biol 13:774-783

Editorial responsibility: Otto Kinne (Editor-in-Chief), Oldendorf/Luhe, Germany
Vitousek PM, Mooney HA, Lubchenco J, Melillo JM (1997) Human domination of Earth's ecosystems. Science 277:494-499

Walker DI, Lukatelich RJ, Bastyan G, McComb AJ (1989) Effect of boat moorings on seagrass beds near Perth, Western Australia. Aquat Bot 36:69-77

Warwick RM, Clarke KR (1993) Increased variability as a symptom of stress in marine communities. J Exp Mar Biol Ecol 172:215-226

Wiens JA (1976) Population responses to patchy environments. Annu Rev Ecol Syst 7:81-120

Wiens JA, Schooley RL, Weeks RD Jr (1997) Patchy landscapes and animal movements: do beetles percolate? Oikos 78:257-264

With KA, Crist TO (1995) Critical thresholds in species' responses to landscape structure. Ecology 76:2446-2459

With KA, Cadaret SJ, Davis C (1999) Movement responses to patch structure in experimental fractal landscapes. Ecology 80:1340-1353

Zieman JC (1976) The ecological effects of physical damage from motor boats on turtle grass beds in southern Florida. Aquat Bot 2:127-139

Submitted: June 21, 2005; Accepted: March 16, 2006 Proofs received from author(s): October 27, 2006 